\title{
Readiness in Applying Higher Order Thinking Skills after Attending Courses
}

\author{
Faziah binti Abd Karim, ${ }^{1 *}$ Tan Jun Cheng ${ }^{1}$ \\ ${ }^{1}$ Institut Perguruan Tun Hussein Onn \\ Batu Pahat, Johor, MALAYSIA \\ *Corresponding Author
}

DOI: https://doi.org/10.30880/jts.2018.10.02.006

\begin{abstract}
The Higher Order Thinking Skills (HOTS) is the ability to apply knowledge, skills and values in making reasoning and reflection to solve problems, make decisions, innovate and create something. This study is aimed at identifying the level and relationship of HOTS in critical thinking skills, problem solving skills, metacognitive skills and decision-making skills used among students of Institut Pendidikan Guru Kampus Tun Hussein Onn (IPGKTHO). A total of 44 teacher trainees who had attended the HOTS course were involved as a sample of the study. Likert scale set with a four-point likert scale has been used in assessing this study. The results show that students of IPGKTHO can master all skills after they had been exposed and trained. The findings also show that there is a significant relationship at the very strong level between all the skills. In conclusion, HOTS is an important skill that teacher trainees must master.
\end{abstract}

Keywords : Critical thinking skills; problem solving skills; metacognitive skills and decision making.

\section{Introduction}

The Malaysian Education Development Plan (PPPM) 2013 - 2025 is a long-term strategic plan aimed at enhancing the quality of national education over a 13-year period with the implementation of comprehensive education reform. Five aspirations of the system and six aspirations of students have been identified as catalysts to drive excellence in the education of the country in the future. Among the successes of the education transformation is the Ministry of Education Malaysia (MOE) intends to put the country in the top third group in international assessments such as TIMSS and PISA within 15 years. Higher Order Thinking Skills (HOTS) and the Implementation of HOTS in Schools are very important to achieve this goal. To achieve that goal, all parties need to support each other and play their roles. Teachers in particular need to equip themselves with new knowledge and skills as well as new teaching and learning practices relevant to the development and needs of the 21 st century and thinking skills across all disciplines among pupils should be given priority. Teacher and pupil's thinking skills, especially in the context of Higher Order Thinking Skills (HOTS), are the requirements or priorities in determining the success of education transformation as outlined in PPPM 2013-2025. 
This is in accordance with the nation's aspiration to gauge students' cognitive performance as expressed in the Executive Summary, Malaysia Education Blueprint (2013-2025, p.E-6). Brookhart (2010) as cited in Collins, R (2014) affirms that one way to inculcate HOTS among pupils is by incorporating these skills in the teachers' lesson plans. Accordingly, the cultivation of thinking skills at primary school level is vital and the assurance that pupils can develop HOTS required in-depth analysis of the planning of lessons. Therefore, infusing HOTS elements in teaching and learning involved teachers' competencies in HOTS and their skills in designing teaching and learning; in considering all elements in a holistic manner; and innovating creative ideas.

The course attended by students including theories of concept and hands on training. PRKA 3012-Planning of Teaching and Learning course was first time introduced to semester 4 students of Institutes of Teacher Education in January 2017 under the component of Professional Practice. The rationale for the inclusion of the course in the Bachelor of Teaching Primary Education Programme is to enable students to master content knowledge and skills to plan and excute teaching and learning. One of the content of the course proforma includes HOTs; i-think, Habits Of Mind (HOM) and Critical and Creative Thinking Skills (CCTS). Also, one of the Transferable Skills (TS) in the content of the course proforma is Critical Thinking and Problem Solving Skills.

\subsection{Critical Thinking Skills}

According to Scriven and Paul (1992), Critical Thinking Skills (CTS) is an intellectual discipline that works actively and proficiently in expressing concepts, making applications, analyzing, synthesizing and evaluating information gathered, generated, response, motivation or communication as a guide to trust and action.

The importance of CTS among students is that it is able to encourage a student to test the truth of a matter or problem in order not to form a wrong conclusion or decision, as well as the ability to process information and produce something new and original. New ideas come through the experience or combination of ideas. Critical thinking can be taught with a variety of strategies and programs that emphasize the way in which the presentation encourages students to think and master the skills and contents of the lessons being delivered (Yahya \& Norhusna, 2007).

\subsection{Problem Solving Skills}

Woods and Colleagues (1975) points out that, The Problem Solving Skills (PSS) is the process of obtaining a satisfactory solution for a new problem or a problem that the individual who tried to solve it has never experienced it. Overall, problem solving involves a series of levels ranging from a problem identifier to a problem and thus leads to the construction of a solution. Troubleshooting can be seen as a structured and oriented process. However, in determining the direction of the solution, we need to define the problem first, followed by the desired goal or required change.

Regardless of whether the problem is small or complex, all need to be resolved in a constructive way. Therefore, PSS is an essential skill in many aspects of our lives whether it is professional or personal. What matters is how we face problems. This will result in an effective or ineffective solution. PSS indeed is an important skill and needs to be acquired by teachers as they can further enhance students' achievement. Students use PSS in solving the task given to them during learning process.

\subsection{Metacognitive Skills}

The metacognitive skills is the ability to understand and analyse one own learning. According to SchrawG,\&Moshman D (1995) Metacognitive Skills (MS) requires learners to set their learning goals, understand their own learning styles and evaluate their own learning. Hence, it is important for students to master the skills to develop self -awareness and the ablity to self-assess. The importance of metacognitive skills as it promotes effective learning by increasing the awareness level in learning thus enabling them to to employ the strategies effectively. Successful trainee teachers are those who learn theories and able to apply them in their practices after mastering metacognitve skills. In addition, mastering metacognitive skills helps them in understanding and resolving complex issues. There is evidence to suggest that teacher trainees who apply reflective reasoning on their development of both cognitive and metacognitve skills are able to solve complex problems.

\subsection{Decision Making Skills}

According to Massie (1987), Decision Making Skills (DMS) are actions that are made consciously from several alternatives aimed at gaining the expected results. Meanwhile, according to Koontz and Dannel (1978), DMS means selection activities from more than one alternative and is the heart of organizational planning.

Individual perceptions of change often affect them in making decisions to achieve optimum benefits and also provide high satisfaction. Hence, often the decisions taken will overturn the reality, justice and rules set out toward the decision 
Faziah Abdul Karim1 et al., Journal of Techno Social, Vol. 10 No. 2 (2018) p. 35-41 making. Ab. Aziz (2004) states that emotional intelligence is needed in making decisions. The decision is a process in which the organization meets the needs of an organization including the burden that will be either positive or negative to obtain the optimum or best decision. Ahmad Atory Hussain (1991) states that the risk situation is based on DMS.

Each risk is based on risks involving the future and this is difficult to predict. The risk situation that occurs when the decision is made based on the possibility of the decision to be found. The likelihood of decisions made can determine almost exactly the available alternative results. The statement was agreed upon by Ab. Aziz Yusof (2004) stating that in order to ensure that one's success will not be trapped in systems and procedures because of their courage to take risks and get out of comfort, they are ready to take full responsibility for the overall achievement by holding and acting proactively towards the change.

\section{Problem Statement}

Critical Thinking Skills of students today is an important thing in the field of education. The current graduates face problems with job opportunities (MTEN 2005). Hence, graduates need to equip themselves with the current market needs of having good 21 st century skills. In addition, among the factors that cause students failure to master critical thinking skills is the lack of emphasis on teaching thinking skills during the teaching and learning process (Phillip, 1992). Hence, the situation in today's classroom is certainly not able to produce an organization for the development of critical and creative thinking (Marzano et al 1988). In this context students do not develop their knowledge. The process of building knowledge is to link newly acquired knowledge with existing knowledge so that the R \& D process is effective.

Problem solving skills among students is still low. This is because many students are unaware and understand what the problem is. They also lack the courage to explore new and best solutions without high risk. Students also found no risk of risk, consequences and failure if they failed to do something. Most of them prefer to settle a problem with a common solution without thinking of high levels of thinking.

Failing to achieve excellent results due to lack in knowledge in mastering metacognitive skills is another problem among learners. The reason for the impairment of students' academic achievement is that they fail to adapt to the way of teaching and learning in the classroom as well as not having the right learning styles (Baharin Abu, 2000, 2003; Abdul Ghani Awang, 1996). They can not find the most appropriate metacognitive skills on their own. This clearly demonstrates the need for a student to master the most appropriate metacognitive skills of himself especially during the classroom learning. The ability to understand and analyse one own learning by each individual is different from each other.

According to Abdul Razak and Ainin (2000) and Chek Mat (2003), problems arise when students do not perform well as expected. Hence the intention of the student to achieve the goal is not achieved. At this point, the student can not make the right decision to deal with the problem. In the context of decision making, student emotions are also unstable. So when they decide, emotions play a role in choosing judgment on the importance of decisions made. According to Jaafar (2000) humans are emotionally involved in doing something. Abdul Aziz (2004) says students make decisions based on assumptions or perceptions of decisions without taking into account the emotional intelligence they possess. Fiedler (1967) in Lynne Millward (2005) states that most critical decisions among students are made under extremely high pressure situations. Desperate circumstances caused by time factors can lead to decisions being made in a hurry. Therefore, it is very important for students to master their decision-making skills to solve the problems faced by them.

\section{Research Objectives}

The specific objectives of this study are to:

- Identify the level of the higher order thinking skills: critical thinking skills, problem solving skills, metacognitive skills and decision-making skills among students.

- Identify the correlation of critical thinking skills with problem solving skills ; metacognitive skills and decision making skills .

\section{Research Questions}

- What is the level of the higher order thinking skills: critical thinking skills, problem solving skills, metacognitive skills and decision-making skills among students?

- Is there a relationship between critical thinking skills with problem solving skills, metacognitive skills and decision-making skills among students? 


\section{Research Methodology}

This study is a quantitative study that aims to identify the level and the relationship between four variables, namely critical thinking skills, problem solving skills, metacognitive skills and decision-making skills. This study was conducted at the IPGK Tun Hussein Onn (IPGKTHO), Batu Pahat among students who are currently undergoing teacher training.

A set of HOTS questionnaire was used based on the Musliha Salma (2010) and was modified according to the suitability of the respondents. This questionnaire was divided into two parts: A and B. Part A contains questions related to student demographics. Part B contains a critical thinking skills questionnaire, problem solving skills, metacognitive skills and decision-making skills.

\section{Findings}

In Table 1, data analysis finds that all skill levels are in place at a high level of critical thinking skills $(\mathrm{min}=3.12$, s.d. $=.52)$, skills to solve problems $(\min =3.1$, s.d. $=.50)$, metacognitive skills $(\min =3.04$, s.d $=.53)$ and decisionmaking skills $(\min =3.07$, s.d. $=.52)$ among the students.

\section{Table 1: Min Score for CTS, PSS, MS and DMS}

\begin{tabular}{|l|l|c|c|c|}
\hline No. & \multicolumn{1}{|c|}{ Skills } & Min & Standard Deviation & Level \\
\hline 1 & Critical Thinking Skills (CTS) & 3.12 & .52 & High \\
\hline 2 & Problem Solving Skills (PSS) & 3.10 & .50 & High \\
\hline 3 & Metacognitive Skills (MS) & 3.04 & .53 & High \\
\hline 4. & Decision Making Skills (DMS) & 3.07 & .52 & High \\
\hline
\end{tabular}

In Table 2, the mean score for each item is at a high level with the overall achievement of the mean level of 3.0. There is a questionnaire that achieves a very high level of item $4(\mathrm{~min}=3.3)$ which shows that students have critical thinking skills in a very high level in terms of "thinking deeply about something".

Table 2: Min Score for Every Critical Thinking Skill Item

\begin{tabular}{|c|l|c|c|}
\hline Item & \multicolumn{1}{|c|}{ When facing a problem, I .... } & Min & Level \\
\hline 1 & associate facts with ideas to describe a problem. & 3.2 & High \\
\hline 2 & think reactive (give comments, comments and rational) & 3.1 & High \\
\hline 3 & compare the ideas that are released. & 3.2 & High \\
\hline 4 & think deeply about something. & 3.3 & Very High \\
\hline 5 & make appropriate judgments about a matter. & 3.2 & High \\
\hline 6 & use technology effectively. & 3.1 & High \\
\hline 7 & use equipment effectively. & 3.0 & High \\
\hline 8 & use the information system well. & 3.1 & High \\
\hline 9 & assess issues from various angles. & 3.1 & High \\
\hline 10 & give thoughtful ideas. & 3.0 & High \\
\hline 11 & express opinions to produce good ideas. & 3.1 & High \\
\hline 12 & give criticism in producing a good idea. & 3.0 & High \\
\hline
\end{tabular}

Table 3 shows the mean score for each item at a high level with the overall achievement of the mean level greater than 3.0 except for item 13 which only reaches min at level 2.8 only. There were two items of questionnaire which reached a very high level of item 19 and item 21 which showed that the students had problem solving skill in a very high level in terms of assessing the problem and solving problems that arise effectively.

Table 3: Min Score for Every Problem Solving Item

\begin{tabular}{|c|l|c|c|}
\hline Item & In solving a problem, I .... & Min & Level \\
\hline 13 & able to identify problems that exist in complex and hazy situations & 2.8 & High \\
\hline 14 & able to get an alternative solution to the problem & 3.0 & High \\
\hline 15 & able to analyze problems that exist & 3.15 & High \\
\hline 16 & able to solve the problem using the necessary skills and knowledge & 3.09 & High \\
\hline 17 & able to visualize something and form the concept of it & 3.22 & High \\
\hline 18 & able to use various techniques to solve problems & 3.06 & High \\
\hline
\end{tabular}


Faziah Abdul Karim1 et al., Journal of Techno Social, Vol. 10 No. 2 (2018) p. 35-41

\begin{tabular}{|l|l|c|c|}
\hline 19 & able to study the given problem & 3.45 & Very High \\
\hline 20 & take a little time to solve complex problems & 3.1 & High \\
\hline 21 & able to solve problems that arise effectively & 3.3 & Very High \\
\hline
\end{tabular}

Table 4 shows the mean score for each item at a high level with the overall achievement of the mean level greater than 3.0 except for item 25 which only reaches mean at 2.9 level only. There were no questionnaires that reached a very high mean of min exceeding 3.25 .

Table 4 : Mean Score for Each Metacognitive Skills Item

\begin{tabular}{|c|l|c|c|}
\hline Item & \multicolumn{1}{|c|}{ During my study, I ... } & Min & Level \\
\hline 22 & use various techniques to solve the problem & 3.02 & High \\
\hline 23 & examine the given problem & 3.06 & High \\
\hline 24 & take a short time to solve complex problems & 2.56 & High \\
\hline 25 & solve problems that arise effectively & 2.9 & High \\
\hline 26 & will be responsible for self-study & 3.1 & High \\
\hline 27 & have very deep curiosity & 3.2 & High \\
\hline 28 & $\begin{array}{l}\text { will seek specialized knowledge from various } \\
\text { fields }\end{array}$ & 3.1 & High \\
\hline 29 & will use specialized knowledge from various fields & 3.0 & High \\
\hline 30 & work hard in doing something to succeed & 3.0 & High \\
\hline 31 & have a high motivation to learn new things & 3.2 & High \\
\hline 32 & use various media to learn (internet, reference & 3.2 & High \\
\hline 33 & $\begin{array}{l}\text { boowill ks) ge t information through queries } \\
\text { with }\end{array}$ & 3.1 & High \\
\hline 34 & $\begin{array}{l}\text { owilthel rslea rn from someone through } \\
\text { observation }\end{array}$ & 3.1 & High \\
\hline
\end{tabular}

Table 5 shows the mean score for most items at a high level with overall reaching the mean level of 3.0 except for item 35 and 41 which only reaches min at level 2.9 only. There is a questionnaire that achieves a very high level of min with a mean value of more than 3.25 which is a 40 item that shows that students have problem-solving skills in a very high level in terms of "being able to choose the most effective solution".

Table 5: Mean Score per Decision-Making Items

\begin{tabular}{|c|l|c|c|}
\hline Item & When making a decision, I .... & Min & Level \\
\hline 35 & using a sharp mind & 2.9 & High \\
\hline 36 & make comparisons & 3.1 & High \\
\hline 37 & $\begin{array}{l}\text { will determine the goal before making a } \\
\text { decision }\end{array}$ & 3.1 & High \\
\hline 38 & consider the risks to make decisions & 3.2 & High \\
\hline 39 & based on the reasons stated & 3.2 & High \\
\hline 40 & able to choose the most effective solution & 3.3 & $\begin{array}{c}\text { Very } \\
\text { High }\end{array}$ \\
\hline 41 & not dependent on others & 2.9 & High \\
\hline 42 & determine what is wrong in a matter & 3.0 & High \\
\hline 43 & able to determine what is right in a matter & 3.0 & High \\
\hline 44 & suggest how it can be done better & High \\
\hline
\end{tabular}

Table 6 shows that there is a significant relationship between the critical thinking skills and problem solving skills $(\mathrm{r}=.975, \mathrm{p}=.000)$, metacognitive skills $(\mathrm{r}=.976, \mathrm{p}=.000)$ and decision making skills $(\mathrm{r}=.98, \mathrm{p}=.000)$. The findings showed that all null hypotheses were successfully rejected which proved that there was a significant relationship between all the variables studied. 
Table 6: Correlation Analysis Between CTS With PSS, MS And DMS

\begin{tabular}{|l|c|c|c|}
\hline \multicolumn{1}{|c|}{ Hypothesis } & $\begin{array}{c}\text { Value } \\
\mathbf{r}\end{array}$ & $\begin{array}{c}\text { Value } \\
\mathbf{p}\end{array}$ & Decision \\
\hline $\begin{array}{l}\text { There was no significant relationship Between } \\
\text { CTS and PSS among students }\end{array}$ & .98 & .000 & Rejected \\
\hline $\begin{array}{l}\text { There was no significant relationship between CTS } \\
\text { with MS among students }\end{array}$ & .98 & .000 & Rejected \\
\hline $\begin{array}{l}\text { There was no significant relationship between CTS } \\
\text { with DNS among students }\end{array}$ & .98 & .000 & Rejected \\
\hline
\end{tabular}

\section{Discussion and Conclusion}

The findings show that overall the skills are in the Critical Thinking Skills (Min = 3.12), problem solving skills (min $=3.1)$, decision making skills $(\mathrm{min}=3.07)$ and metacognitive skills $(\mathrm{min}=3.04)$. This finding shows that students can master all skills if they have been exposed and trained. Zamri (2014) who finds knowledgeable teachers in HOTS can provide exposure on HOTS to their students and will be able to bring teaching and learning to a higher order of thinking. These teachers can also apply various teaching techniques such as creating problem-solving discourses, making decisions, making an inference, suggesting new ideas and also evaluating actions that all of these activities are the characteristics of HOTS.

The findings also show that there is a significant relationship at the very strong level between all the variables between critical thinking skills, problem solving skills, metacognitive skills and decision-making skills. Studies on the relationship between critical thinking skills, problem solving skills, metacognitive skills and decision-making skills have indeed showed a significant relationship between all variables (Day and Halpin; 2004, Van Knippenberg And Hogg, 2003). This high relationship is because all of these variables are the main skills needed and mastered among students. This high level of relationship is also due to the importance of generic skills that have been continuously practised by the students.

In conclusion, critical thinking skills, problem solving skills, metacognitative skills and decision making skills are part of the skills that are in higher order thinking skills and should be mastered by students at institutes of higher education in preparing themselves for the current job market. A student's thinking ability can influence their learning styles, learning ability and their effectiveness of learning. The ability to transfer skills across multiple situations is very important and it is acquired all through a person's life. Skillful thinker will understand how to adapt their learning and successfully find their way in new environment. Therefore, HOTS is the most important skill to enhance the knowledge gained and the students' success. This study should open a new dimension in looking at "Learning Outside The Box" which begins with a Higher Order Thinking Skills.

\section{References}

Anjakan (2015). PADU (Unit Pelaksanaan dan Prestasi Pendidikan) Kementerian Pendidikan Malaysia, Putrajaya.

Azizi Yahya, Safiah Sidek \& Zanariah Jano. (2011). Critical Thinking Skills Among Final Year Students of Malaysian Technical Universities. Malaysian Technical Universities International. Conference on Engineering \& Technology (MUiCET 2011). UTEM. Jurnal Psikologi Malaysia 30 (1) (2016): 142-151.

Collins, $\mathrm{R}$ (2014) Skills in the 21st Century: Teaching HOTS. Retrieved from http://www.curriculum.edu.au/leader/teaching_higher_order_thinking, 37431.html?issueID=12910

Day, D. (2001). Leadership Development: A Review in Context. Leadership Quaterly, 11, 581-613.

Day, D., \& Halpin, S. (2004). Growing leaders for tomorrow: An Introduction. In Day, D., Zaccaro, S., \& Haqlpin, S. (Eds), Leader Development for Transforming Organizations: Growing Leaders for Tomorrow. Eribaum, Mahwah (3pp22. New Jersey.

Kathiravelu, A., Tapsir, R., \& Osman, A.M. (2004). Meta Cognitive And Critical Thinking Abilities of Students at INTEC: Institute of Research, Development and Commercialisation (IRDC), UiTM Shah Alam, Selangor.

Mohd Najib Abdul Aziz dan Nor Shafrin Ahmad (2008). Kemahiran Belajar dan Hubungannya dengan Pencapaian 
Musliha Salma Mohd Radzi (2010).Aplikasi Kemahiran Berfikir Aras Tinggi Melalui Pembelajaran Berasaskan Masalah. Skudai; UTM.

Schraw G., \& Moshman D. (1995). Metacognitive Theories. Educational Psychology Review, 7(4), $351-371$.

Scriven and Paul (1992), National Council for Excellence in Critical Thinking
.Retrieved from https://www.crc.losrios.edu/files/cassl/DefiningCriticalThinkingc2.pdf

Siti Zabidah Mohamed. (2006). Kesan Pendekatan Penyebatian Kemahiran Berfikir Kreatif dalam Pengajaran Karangan Deskriptif dan Karangan Imaginatif dalam Kalangan Pelajar Tingkatan IV. Disertasi Ph.D. USM.

Sugiyono, D. (2001). Metode Penelitian Administrasi, Penerbit Alfabeta Bandung.

Syahida Nadia Zakaria. (2015). Kesan Pendekatan Konstruktivisme dan Pendekatan Tradisional dalam Pengajaran dan Pembelajaran Komponen Sastera Bahasa Melayu. Jurnal Pendidikan Bahasa Melayu, 5 (2): 12-21.

Van Knippenberg, D., \& Hogg, M. A. (2003). A Social Identity Model of Leadership Effectiveness in Organizations. Journal Research in Organizational Behavior, 25, 243-295.

Yahya Buntat (2004) Integrasi Kemahiran "Employability” dalam Program Pendidikan Vokasional Pertanian dan Industri Di Malaysia. Thesis Phd.

Zamri Mahamod \& Nor Razah Lim. (2011). Kepelbagaian kaedah penyoalan lisan dalam pengajaran Bahasa Melayu: Kaedah Pemerhatian. Jurnal Pendidikan Bahasa Melayu, 1 (5): 51-65.

Zamri Mahamod, Ruslin Amir \& Mohamed Amin Embi. 2015. Kepelbagaian pelajar dan perbezaan pembelajaran. Kuala Lumpur: Dewan Bahasa dan Pustaka.

Zamri Mahamod. 2014. Inovasi P\&P dalam pendidikan Bahasa Melayu. Cetakan Ketiga. Tanjung Malim: Penerbit UPSI.

Zamri Mahamod. (2015). Strategi pembelajaran: Inventori Cara Belajar Bahasa Melayu. Kuala Lumpur: Dewan Bahasa dan Pustaka. 